\title{
Nieuw onderzoek naar thuis zuurstofsaturatie meten bij COVID-19-patiënten
}

Karin Smit

Het veilig volgen van patiënten met COVID-19 vormt een uitdaging voor huisartsen, omdat de klinische conditie en lage zuurstofsaturatie niet altijd synchroon lopen met de ernst van de klachten. Het systematisch thuis meten van de zuurstofsaturatie door de patiënt kan uitkomst bieden. Wetenschappelijke onderbouwing hiervoor ontbreekt echter. In deze pilot onderzoeken we de haalbaarheid van thuismonitoring van zuurstofsaturatie met pulsoximetrie.

Huisartsen volgen patiënten met matig-ernstige COVID-19klachten doorgaans nauwgezet om eventuele klinische verslechtering te signaleren. Bij sommige patiënten gaan lage zuurstofsaturatiewaarden echter niet gepaard met benauwdheid, wat ook wel happy hypoxemia wordt genoemd. ${ }^{1-3}$ Een plotselinge daling van de zuurstofsaturatie lijkt vooral tussen ziektedag 5 en 10 op te treden. Dit is een belangrijke parameter van klinische verslechtering. Het vroegtijdig signaleren en behandelen van hypoxemie kan belangrijke gezondheidswinst opleveren, vooral bij patiënten met onderliggend cardiovasculair lijden en een groter risico op een ongunstig beloop., ${ }^{4,5}$ Het CovidSat@Home-onderzoek richt zich op mensen van 40 jaar en ouder met matig-ernstige klachten van (vermoedelijk) COVID-19 bij wie sprake is van een cardiovasculaire ziekte of risicofactoren, en bij wie de huisarts zorgvuldige follow-up wenselijk acht. Het betreft een gerandomiseerd gecontroleerd pilotonderzoek naar de haalbaarheid van thuismonitoring van zuurstofsaturatie met een gevalideerde pulsoximeter. We wijzen 50 patiënten ( 2 maal 25) door loting toe aan pulsoximetergebruik naast de gebruikelijke huisartsenzorg (interventiegroep) of gebruikelijke huisartsenzorg zonder pulsoximeter (controlegroep). De interventiegroep zal gedurende de ziekteperiode 3 keer per dag (in rust) de zuurstofsaturatie meten en naar eigen inzicht extra metingen uitvoeren. Bij $\mathrm{SpO}_{2}<94 \%$ worden patiënten verzocht contact op te nemen met hun huisarts. ${ }^{6}$ Behalve inzicht geven in de haalbaarheid zal het onderzoek ook laten zien welke impact het thuis meten van de zuurstofsaturatie heeft op het gevoel van veiligheid van de patiënt.

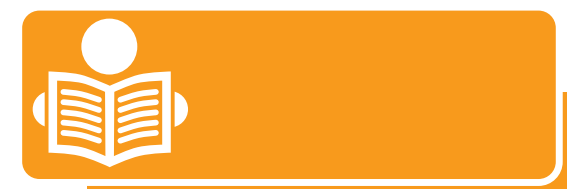
zijn... Huisarts Wet 2021;64[4]:43-4.

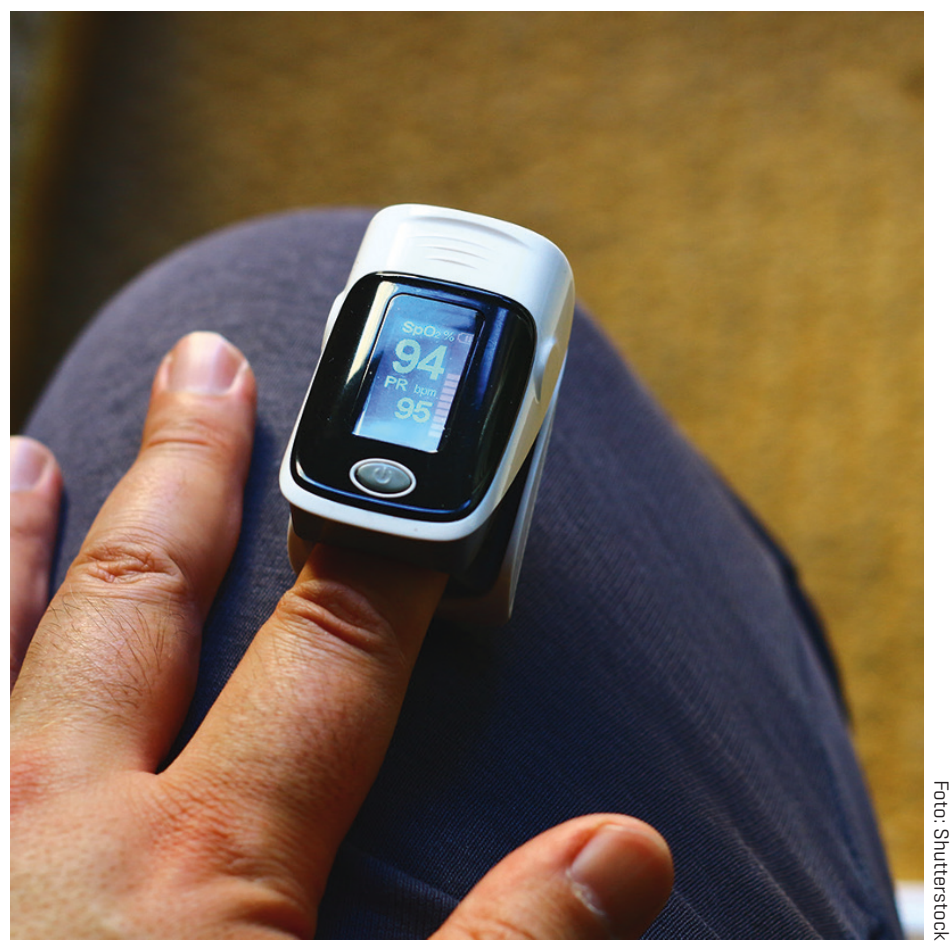

Het onderzoek loopt van november 2020 tot mei 2021. De eerste resultaten worden in de tweede helft van 2021 verwacht.

\section{LITERATUUR}

1. Cascella M, Rajnik M, Cuomo A, et al. Features, evaluation and treatment coronavirus (COVID-19). In: StatPearls. Treasure Island (FL): StatPearls Publishing, 2020.

2. Dhont S, Derom E, Van Braeckel E, et al. The pathophysiology of 'happy' hypoxemia in COVID-19. Respir Res 2020;21:198.

3. Couzin-Frankel J. The mystery of the pandemic's 'happy hypoxia'. Science 2020;368:455-6.

De volledige literatuurlijst staat bij dit artikel op www.henw.org.

Smit K. Nieuw onderzoek naar thuis zuurstofsaturatie meten bij COVID-19patiënten. Huisarts Wet 2021;64[4]:75. D0l:10.1007/s12445-021-1070-x. Universitair Medisch Centrum Utrecht, afdeling Huisartsgeneeskunde, Divisie Julius Centrum voor Gezondheidswetenschappen en Eerstelijnsgeneeskunde, Utrecht: K. Smit, onderzoeker en huisarts-in-opleiding, k.smit-7@umcutrecht. nl.

Mogelijke belangenverstrengeling: het onderzoek is mede gefinancierd door de Nederlandse Hartstichting.

Dit is een bijdrage in de rubriek Lopend onderzoek, relevant voor de eerste lijn, geschreven door een promovendus. 